\title{
Manfaat Sosial Bank Sampah di Kecamatan Lubuk Kilangan Kota Padang
}

\author{
Emilia Ramadani \\ Prodi Pendidikan Pancasila dan Kewarganegaraan \\ FIS Universitas Negeri Padang \\ E-mail: ramadaniemilia@gmail.com
}

\begin{abstract}
ABSTRAK
Penelitian ini bertujuan untuk mengidentifikasi manfaat sosial bank sampah di Kecamatan Lubuk Kilangan Kota Padang. Penelitian ini menggunakan jenis penelitian deskriptif kualitatif. Adapun data informan yaitu beberapa Direktur Bank Sampah, tokoh masyarakat Kecamatan Lubuk Kilangan, Lurah Banda Buek, Lurah Batu Gadang, Ketua Lembaga Pemberdayaan Masyarakat Banda Buek, dan Lembaga Pemberdayaan Masyarakat Batu Gadang. Lokasi penelitian ini berada di Kelurahan bandar buat dan kelurahan batu gadang di Kecamatan Lubuk Kilangan Kota Padang. Tekhnik pengumpulan data yang digunakan yaitu menggunakan tekhnik observasi, wawancara dan dokumentasi. Uji keabsahan data dilakukan melalui teknik triangulasi, kemudian analisis dengan cara reduksi data, penyajian data, dan selanjutnya disimpulkan untuk penulisan. Hasil penelitian menunjukkan bahwa pelaksanaan kegiatan pengelolaan sampah di bank sampah dengan pedekatan reduce, reuse dan recycle telah terlaksana namun belum optimal. Manfaat sosial Bank sampah di Bank Sampah Hidayah dan bank sampah sakinah yaitu mengubah persepsi warga yang sebelumya menganggap sampah sebagai sesuatu yang tidak bernilai ekonomis menjadi bernilai ekonomis setelah dimanfaatkan, membuka lapangan pekerjaan baru, adannya perubahan perilaku masyarakat dalam pengelolaan sampah. Hasil tabungan nasabah di bank sampah dipergunakan untuk biaya pendidikan anak-anaknya serta adanya program menabung sampah di TK Mutiara dan TK Sani Ashilla untuk membayar uang SPP-nya.
\end{abstract}

\section{Kata Kunci: sampah, bank sampah, manfaat sosial}

\section{ABSTRACT}

This study aims to identify the social benefits of waste banks in Lubuk Kilangan District, Padang City. This research uses descriptive qualitative research. The informants' data were several directors of the Waste Bank, community leaders in Lubuk Kilangan District, Banda Buek Village Head, Batu Gadang Village Head, Head of the Banda Buek Community Empowerment Institute, and the Batu Gadang Community Empowerment Institute. The location of this research is in the urban village of Bandarbuat and the village of Batu Gadang in Lubuk Kilangan District, Padang City. The data collection technique used is using observation, 
interview and documentation techniques. The data validity test was carried out through triangulation techniques, then analyzed by means of data reduction, data presentation, and then concluded for writing. The results of the study indicate that the implementation of waste management activities in the waste bank with the reduce, reuse and recycle approach has been implemented but is not optimal. The social benefits of the Garbage Bank at the Hidayah Garbage Bank and the Sakinah Garbage Bank are changing the perception of residents who previously considered waste as something that has no economic value to become economically valuable after being used, opening new jobs, and changing community behavior in waste management. The results of customer savings in the waste bank are used for the education costs of their children and there is a waste saving program at Mutiara Kindergarten and Sani Ashilla Kindergarten to pay their tuition fees.

\section{Keywords: garbage, garbage bank, social benefits}

(1) (2) This work is licensed under the Creative Commons Attribution-ShareAlike 4.0 International License. (C) 2021 by author.

\section{PENDAHULUAN}

Sampah merupakan permasalahan lingkungan yang telah mengakar dan menjadi permasalahan yang sangat serius dalam kehidupan manusia. Undang-Undang Nomor 18 Tahun 2008 tentang Pengelolaan Sampah serta Peraturan Pemerintah Nomor 81 Tahun 2012 tentang Pengelolaan Sampah Rumah Tangga dan Sampah Sejenis Sampah Rumah Tangga mengamanatkan sudah saatnya paradigma pengelolaan sampah yang bertumpu pada pendekatan akhir ditinggalkan dan diganti dengan paradigma baru yaitu Paradigma yang menganggap sampah sebagai sumber daya yang mempunyai nilai ekonomis dan dapat dimanfaatkan, misalnya, untuk energi, kompos, pupuk, dan bahan baku industri. Kementerian Lingkungan Hidup (KLHK) telah melakukan upaya untuk mengembangkan paradigma baru tersebut dengan menghadirkan program pengembangan Bank Sampah.

Bank Sampah adalah tempat menabung sampah yang telah terpilah menurut jenis sampah. Cara kerja bank sampah pada umumnya hampir sama dengan bank lainnya yaitu ada nasabah, pencatatan pembukuan dan manajemen pengelolaannya. Apabila dalam bank umum yang disetorkan nasabah adalah uang, akan tetapi dalam bank sampah yang disetorkan adalah sampah yang mempunyai nilai ekonomis Aryenti (dalam Suryani 2011). Andi,dkk (2017) Adapun fungsi dari Bank Sampah yaitu merupakan tempat menabung sampah yang telah terpilah menurut jenis sampah, sampah yang ditabung pada bank sampah adalah sampah yang mempunyai nilai ekonomis. 
Direktur Bank Sampah Hidayah mengatakan bahwa pada awal pendirian untuk mengajak masyarakat masih sulit, hingga saat ini pun masih sulit. Pada awalnya, jumlah nasabah sebanyak 30 , saat ini 70 orang hanya saja yang aktif hanya $10 \%$ dimana kesadaran masayarakat dalam memilah sampah serta mengantarkannya ke bank sampah yang belum optimal. Selanjutnya, berdasarkan wawancara peneliti dengan direktur bank sampah sakinah pada Juli 2020 menjelaskan faktor penghambatnya, kepedulian masyarakat yang belum mencapai $50 \%$ serta kesadaran masyarakat yang masih kurang.

Berdasarkan grandtour dengan direktur bank sampah sakinah buk Asri pada bank sampah sakinah dibentuk pada tahun 2012, jenis sampah yang diolah yaitu sampah anorganik berupa sampah plastik yang bersumber dari rumah tangga. Jumlah nasabah saat ini 475 nasabah, dimana tidak ada batasan umur untuk nasabah. Bahkan anak TK diajarkan untuk menabung dibank sampah sakinah sekaligus untuk mencicil pembayaran SPP-nya. Pelaksanaan pengambilan sampah ada 2 cara. Pertama, tim lapangan dari bank sampah sakinah yang menjemput kerumah, akan tetapi pihak rumah membayar Rp. 20.000/Bulan. Kedua, masyarakat secara mandiri mengantarkan sampah plastik yang telah terpilah ke bank sampah dan dibayarkan. Untuk satu kilogramnya seharga Rp. 6.000,-- Sampah yang telah terpilah biasanya diolah menjadi tas daur ulang dimana Bu Asri menyediakannya jika ada yang memesannya, harga satuan tas nya Rp. 50.000,-. Untuk yang mengolahnya, beliau mengedukasi masyarakat agar mampu mengolah sampah plastik menjadi barang yang bisa dijual. Saat ini tenaga penjahit berjumlah 18 orang, diantarannya ada 9 orang ibu single parent. Manfaat yang dirasakan yaitu menambah pendapatan, menciptakan lapangan perkerjaan baru, sampah plastik sudah mulai berkurang. Faktor penghambatnya, kepedulian masyarakat yang belum mencapai 50\% serta kesadaran masyarakat yang masih kurang.

Penelitian mengenai bank sampah telah banyak dilakukan oleh peneliti terdahulu diantaranya oleh Mita Novianty yang berjudul "Dampak Program Bank Sampah terhadap Sosial Ekonomi Masyarakat di Kota Binjai, Kecamatan Medan Anai, Kota Medan". Hasil penelitian ini menunjukkan adanya dampak positif terhadap kehidupan sosial ekonomi masyarakat di Kota Binjai dengan dihadirkannya pembangunan bank sampah. Dalam aspek ekonomi terlihat adanya penambahan pemasukan pendapatan masyarakat meskipun sedikit akan tetapi bermanfaat bagi masyarakat. Bukan hanya pendapatan yang meningkat, akan tetapi kesehatan dan interaksi sosial lebih baik diantara masyarakat dan lingkungan menjadi lebih bersih. Penelitian selanjutnya yang dilakukan oleh Novia Maria yang berjudul "Upaya Peningkatan Pendapatan Masyarakat Melalui Program Bank Sampah di Kota Bukittinggi". Hasil penelitian dapat disimpulkan bahwa dengan 
adannya program bank sampah membantu mengelola sampah secara efektif dan efisien. Nasabah bank sampah mampu berpartisipasi dalam setiap kegiatan yang diadakan bank sampah seperti pelatihan keterampilan dengan memanfaatkan sampah anorganik. Masyarakat mendapatkan tambahan pendapatan dari hasil tabungan sampah. Bank sampah juga mampu menambah pengetahuan serta wawasan sekaligus kesadaran masyarakat dalam memilah sampah. Dampak program bank sampah mutiara indah terhadap pendapatan masyarakat adalah dapat menambah uang saku bagi anak mereka yang sekolah serta memebuhi kebutuhan rumah tangga lainnya. Berdasarkan penelitian-penelitian di atas peneliti ingin melakukan penelitian yang berbeda dengan penelitian tersebut dengan memfokuskan penelitian pada manfaat sosial Bank Sampah, terkhusus pada Bank Sampah yang bertempat di Kecamatan Lubuk Kilangan Kota Padang.

\section{METODE PENELITIAN}

Jenis penelitian ini adalah kualitatif dengan pendekatan deskriptif. menurut Sudaryono (2018:91) berpendapat bahwa penelitian kualitatif merupakan penelitian yang berupaya menganalisis kehidupan sosial dengan menggambarkan dunia sosial dari sudut pandang atau interpretasi individu (informan) dalam latar ilmiah. Dengan kata lain, penelitian kualitatif berupaya memahami bagaimana seorang individu melihat, memaknai atau menggambarkan dunia sosialnya. Lokasi penelitian ini di kelurahan Bandar Buat dan kelurahan Batu Gadang Lubuk Kilangan Kota Padang. Lokasi ini dipilih untuk menjadi tempat yang akan diteliti untuk memfokuskan kegiatan bank sampahnya. Informan penelitian terdiri dari yaitu tokoh masyarakat, Direktur Bank Sampah Hidayah, Direktur Bank sampah sakinah, Nasabah bank sampah hidayah, Nasabah Bank Sampah Sakinah, Lurah Batu Gadang Kecamatan Lubuk Kilangan Kota Padang, Lurah Banda Buek Kecamatan Lubuk Kilangan Kota Padang, Kasi Komunikasi Lingkungan Dinas Lingkunga Hidup Kota Padang, LPM Banda buek, dan LPM Batu Gadang. Teknik pengumpulan data pada peneitian ini menggunakan metode wawancara, observasi, dan studi dokumentasi. Teknik analisis data dengan menggunakan pengumpulan data, eduksi data, penyajian data, dan menarik kesimpulan atau verifikasi.

\section{HASIL DAN PEMBAHASAN}

Pelaksanaan Pengelolaan Bank Sampah Hidayah di Kelurahan Bandar Buat dan Bank Sampah Sakinah di Kelurahan Batu Gadang

Pelaksanaan Pengelolaan sampah di Indonesia mengacu pada Undang-Undang Nomor 18 Tahun 2008, yaitu pengelolaan 
sampah melalui pendekatan reduse, reuse, dan recycle atau sering dikenal dengan 3R. Konsep 3R (Reduce, Reuse dan Recycle) yang merupakan sebuah metode baru dalam pengelolaan sampah. Untuk itu peneliti ingin melihat lebih jauh pelaksanaan pengelolaan sampah dengan metode $3 \mathrm{R}$. Tahap pengelolaan sampah modern terdiri dari 3R. Penanganan sampah 3-R adalah konsep penanganan sampah dengan cara Reduce adalah prinsip melakukan pengurangan barang atau material yang digunakan. Reuse (menggunakan kembali), Prinsipnya adalah menggunakan kembali barang-barang yang masih bias digunakan. Recycle (mendaur ulang sampah), prinsipnya adalah mendaur ulang barangbarang yang dapat didaur ulang menurut Cunningham (dalam Hadnan,dkk 2015 ).

\section{Bank Sampah Hidayah}

Berdasarkan temuan peneliti dilapangan, pelaksanaan bank sampah hidayah dilakukan dengan cara nasabah yang mengantarkan sampah yang telah terpilah kepada bu Defriyeni dahar. Kemudian ditimbang dan selanjutnya dihargai sesuai uang. Dalam kurun waktu 3 bulan masyarakat menabung di bank sampah hidayah dapat mengambil uangnya.

Berdasarkan temuan dilapangan peneliti menilai bahwa pelaksanaan pengelolaan bank sampah di Bank Sampah Hidayah sudah berjalan dengan baik. Pertama, kegitan reduce telah dilakukan oleh bank sampah hidayah dengan memberikan edukasi kepada masyarakat melalui sosialisasi yaitu dalam berbelanja tidak menggunakan plastik tetapi menggunakan keranjang untuk membawa barang belajannya, serta dengan mengurangi pemakaian barang yang menghasilkan sampah plastik. Akan tetapi hal ini belum berjalan optimal. Kedua, kegiatan reuse ini telah dilakukan di bank sampah hidayah. Dimana masyarakat telah memanfaatkan kembali sampah dari botol-botol aqua dijadikan vas bunga dan ekobrik.

Ketiga, kegiatan recycle telah dilaksanakan di bank sampah hidayah yang ada di Kecamatan Lubuk Kilangan Kota Padang yaitu mengolah sampah denga bahan baku plastik menjadi sebuah produk yang bernilai ekonomis yang memiliki harga jual yang tinggi jika sudah didaur ulang. Tahapan untuk mendaur ulang antara bank sampah hidayah yaitu melakukan pengumpulan sampah yang telah diberikan nasabah secara terpilah. Kemudian melakukan pembersihan, penyortiran sampah plastik dengan mengumpulkan barang-barang yang sejenis, kemudian diolah yaitu dijahit menjadi sebuah produk daur ulang. Bentuk produk yang dihasilkan dari bank sampah hidayah tas keranjang, tas cincang, tas dari bungkusan minyak.

\section{Bank Sampah Sakinah}

Bank sampah sakinah dalam pelaksanaan pengambilan sampah di lakukan dengan dua cara. Pertama, masyarakat secara mandiri mengantarkan sampah plastik yang telah terpilah ke bank sampah 
dan dibayarkan. Untuk satu kilogramnya seharga Rp. 6.000,-. Kedua, tim koordinator lapangan bank sampah sakinah sebanyak 3 orang menjemput kerumah warga dan pembayaran dilakukan oleh warga yaitu Rp.20.000/bulan

Pertama, pada kegiatan reduce di bank sampah sakinah memberikan edukasi kepada masyarakat untuk mengurangi pemakaian sampah plastik. Untuk berbelanja ke pasar, ibuk-ibuk di kelurahan batu gadang menggunakan tas keranjang. Hal ini merupakan bagian dari pengurangan sampah plastik, akan tetapi yang menjalankannya masih sebagian kecil dari masyarakat. Kedua, yaitu kegiatan reuse telah dilaksanakan dengan memanfaatkan kembali buku-buku yang masih bisa dipakai. Kemudian masyarakat memanfaatkan botol-botol aqua dijadikan vas bunga.

Ketiga, recycle telah dilaksanakan sampah tersebut diolah menjadi produk yang memiliki nilai jual yaitu tas dan lainnya. Tahap-tahap daur ulang di Bank Sampah Sakinah dimulai dengan penyortiran sampah plastik dengan memilah sampah plastik dengan sampah sejenis. Misalnya sampah plastik produk white coffee di pilah kemudian di kelompokkan dengan produk sejenis. Sampah plastik cappucino dipilah kemudian dikelompokkan dengan sejenisnya. Selanjutnya yaitu kegiatan menjahit sampah plastik untuk dijadikan produk yang memiliki nilai jual. Produknya berupa tas daur ulang, celemek, tas dari gelas minuman, harga satu produk tas yaitu Rp.50.000.

\section{Manfaat sosial Bank Sampah di Kecamatan Lubuk Kilangan Kota Padang}

Menurut Safiah (2017) manfaat sosial dengan adannya bank sampah, dapat dilihat dari 3 indikator yaitu persepsi warga, jumlah tenaga kerja yang terserap, dan tidaknya perubahan perilaku masyarakat.

\section{Bank Sampah Hidayah}

Pertama, persepsi warga. Berdasarkan temuan peneliti dilapangan pada bank sampah hidayah, dengan adannya bank sampah ini telah memberikan persepsi kepada nasabah, dimana sampah yang dahulu dianggap tidak memiliki manfaat biasanya mereka buang, kemudian setelah adannya bank sampah hidayah pengetahuan akan hal itu berubah dan menganggap sampah menjadi sesuatu yang mempunyai manfaat.

Kedua, Jumlah tenaga kerja yang terserap. Untuk nasabah bank sampah hidayah, menabung di bank sampah hidayah dijadikan untuk pekerjaan tambahan untuk menambah pemasukan keluarganya. Kemudian untuk pengelola bank sampah hidayah sendiri, pengelola bank sampah membuka lapangan kerja untuk kerabatnya apabila dalam kondisi pemesanan produk daur ulang dalam jumlah yang banyak. Ketiga, ada tidaknya perubahan perilaku masyarakat. Pada bank sampah hidayah peneliti menilai dengan adanya bank sampah 
telah memberikan perubahan perilaku kepada nasabah bank sampah hidayah. Sampah yang dulunya dianggap tidak memiliki manfaat, setelah adanya bank sampah warga mulai memilah sampah dan mengantarkannya ke bank sampah.

Dengan adannya bank sampah telah memberikan kontribusi untuk pendidikan. Nasabah bank sampah hidayah menggunakan tabungannya untuk keperluan pendidikan anak-anaknya. Kemudian salah seorang nasabah bank sampah hidayah yang menjabat sebagai kepala sekolah di TK Sani Ashillah melaksanakan kegiatan program spp gratis dengan murid menabung sampah di TK Sani Ashilla untuk memberikan edukasi untuk murid TK-nya menabung sampah agar murid dalam menanamkan karakter peduli lingkungan dari usia dini.

\section{Bank Sampah Sakinah}

Pertama, persepsi warga sekitar diketahui bahwasannya masyarakat dahulu memiliki pengetahuan bahwa sampah itu tidak bermanfaat, sampahnya ada yang dibuang dan juga dibakar. Namun setelah adanya bank sampah pengetahuan nasabah akan sampah mulai berubah dengan menganggap sampah memiliki manfaat.

Kedua, dengan hadirnya bank sampah sakinah telah membuka lapangan pekerjaan bagi masyarakat sebanyak 18 orang tenaga kerja, 9 diantaranya adalah seorang ibu tunggal. Pekerja di bank sampah sakinah ada yang menjahit sebagai pekerjaan utamanya untuk memenuhi kebutuhan hidup sehari-hari. Ketiga, adannya perubahan perilaku masyarakat. Adanya bank sampah sakinah telah memberikan perubaha perilaku kepada nasabah bank sampah sakinah. Sampah yang dulunya dianggap tidak memiliki manfaat mereka buang saja. Namun setelah mengetahui manfaatnya disisihkan dan ditabung ke bank sampah. Sampah yang dibuang kesungai sudah mulai berkurang.

Hadirnya bank sampah sakinah telah memberikan kontribusi untuk pendidikan. Bank sampah sakinah memberikan dorongan kepada murid-muridnya di TK Mutiara dengan mensosialisasikan ke orang tuannya menabung sampah di bank sampah sakinah untuk membayar uang SPP anak-anaknya. Adanya program ini telah membantu meringankan orang tua murid dalam membiayai uang SPP anaknya serta membantu mengurangi jumlah sampah plastik yang ada.

\section{KESIMPULAN}

Pelaksanaan pengambilan sampah di bank sampah hidayah dilakukan dengan cara nasabah yang mengantarkan sampah yang telah terpilah, kemudian ditimbang, selanjutnya dihargai sesuai uang yang telah didapatkan dalam kurun waktu 3 bulan. Sementara pelaksanaan pengambilan sampah dilakukan dengan dua cara. Pertama, masyarakat secara mandiri mengantarkan sampah plastik yang telah terpilah ke Bank Sampah dan dibayarkan. Kedua, tim koordinator lapangan bank sampah sakinah sebanyak 3 orang 
menjemput kerumah warga. Pelaksanaan kegiatan pengelolaan sampah di bank sampah hidayah dan sakinah dengan menggunakan pendekatan Reuse, Reduce dan Recycle telah berjalan akan tetapi belum optimal. Faktor-faktor penghambat pelaksanaan pengelolaan bank sampah hidayah yaitu pemahaman masyarakat, penganggaran, pemasaran, sumber daya manusia, koordinasi antar satuan kerja. Sementara Faktor-faktor penghambat pelaksanaan pengelolaan bank sampah sakinah yaitu kesadaran dan pola pikir masyarakat. Manfaat sosial bank sampah di Bank Sampah Hidayah dan Sakinah yaitu mengubah persepsi warga yang sebelumya menganggap sampah sebagai sesuatu yang tidak bernilai ekonomis menjadi bernilai ekonomis setelah dimanfaatkan, membuka lapangan pekerjaan baru, adannya perubahan perilaku masyarakat dalam pengelolaan sampah, dan hasil tabungan nasabah di bank sampah dipergunakan untuk biaya pendidikan anak-anaknya.

\section{DAFTAR PUSTAKA}

Novia, Maria. 2020 Upaya Peningkatan Pendapatan Masyarakat Melalui Program Bank Sampah di Kota Bukittinggi. Jurnal Of Civic Education. Vol 3, No 1.

Novianty. 2013. Dampak Program Bank Sampah terhadap Sosial Ekonomi Masyarakat di Kelurahan Binjai, Kecamatan medan Denai, Kota Medan [skripsi]. Medan: Fakultas Ilmu Sosial dan Ilmu Politik Universitas Sumatera Utara.

Peraturan Pemerintah Nomor 81 Tahun 2012 tentang Pengelolaan Sampah Rumah Tangga dan Sampah Sejenis Sampah Rumah Tangga.

Risma, Dwi Arisona. 2018. Pengelolaan Sampah 3R (Reduce, Reuse, Recycle) pada pembelajaran IPS untuk menumbuhkan karakter peduli lingkungan. Jurnal IImu Pendidikan Islam. Volume 3 Nomor 1.

Safiah. 2017. Manfaat Bank Sampah Bagi Masyarakat di Dusun Semali Desa Salamkanci Kecamatan Bandongan Kabupaten Magelang. (Study Bank Sampah Semali Berseri). Jurnal Riset Ekonomi Pembangunan. Vol. 2 No 2.

Suryani.2014. Peran Bank Sampah dalam Efektifitas Pengelolaan sampah (Studi Kasus Bank Sampah Malang). Jurnal Aspirasi. (Vol. 5 No.1, Juni 2014)

Undang-Undang Nomor 18 Tahun 2008 tentang Pengelolaan Sampah Wuri. 2015. Perencanaan Bank Sampah dalam rangka pemberdayaan masyarakat di Kecamatan Kepanjen Kabupaten Malang. Jurnal Reformasi Vol. 5, No 1 